Article

\title{
Mapping Flood Risk Uncertainty Zones in Support of Urban Resilience Planning
}

\author{
Sven Anders Brandt ${ }^{1, *}$, Nancy Joy Lim ${ }^{1}$, Johan Colding ${ }^{2,3}$ and Stephan Barthel ${ }^{2,4}$ \\ ${ }^{1}$ Department of Computer and Geospatial Sciences, University of Gävle, Sweden; E-Mails: sab@hig.se (S.A.B.), \\ naylim@hig.se (N.J.L.) \\ 2 Department of Building Engineering, Energy Systems and Sustainability Science, University of Gävle, Sweden; \\ E-Mails: joncog@hig.se (J.C.), stnbal@hig.se (S.B.) \\ ${ }^{3}$ The Beijer Institute of Ecological Economics, Royal Swedish Academy of Sciences, Sweden \\ ${ }^{4}$ Stockholm Resilience Centre, Stockholm University, Sweden \\ * Corresponding author
}

Submitted: 30 January 2021 | Accepted: 21 April 2021 | Published: 19 August 2021

\begin{abstract}
River flooding and urbanization are processes of different character that take place worldwide. As the latter tends to make the consequences of the former worse, together with the uncertainties related to future climate change and flood-risk modeling, there is a need to both use existing tools and develop new ones that help the management and planning of urban environments. In this article a prototype tool, based on estimated maximum land cover roughness variation, the slope of the ground, and the quality of the used digital elevation models, and that can produce flood 'uncertainty zones' of varying width around modeled flood boundaries, is presented. The concept of uncertainty, which urban planners often fail to consider in the spatial planning process, changes from something very difficult into an advantage in this way. Not only may these uncertainties be easier to understand by the urban planners, but the uncertainties may also function as a communication tool between the planners and other stakeholders. Because flood risk is something that urban planners always need to consider, these uncertainty zones can function both as buffer areas against floods, and as blue-green designs of significant importance for a variety of ecosystem services. As the Earth is warming and the world is urbanizing at rates and scales unprecedented in history, we believe that new tools for urban resilience planning are not only urgently needed, but also will have a positive impact on urban planning.
\end{abstract}

\section{Keywords}

digital elevation models; ecosystem services; flood map uncertainties; GIS tool; river floods; urban resilience

\section{Issue}

This article is part of the issue "Smart Urban Governance for Climate Change Adaptation" edited by Thomas Thaler (University of Natural Resources and Life Sciences, Austria), Patrick Witte (Utrecht University, The Netherlands), Thomas Hartmann (TU Dortmund University, Germany) and Stan Geertman (Utrecht University, The Netherlands).

(C) 2021 by the authors; licensee Cogitatio (Lisbon, Portugal). This article is licensed under a Creative Commons Attribution 4.0 International License (CC BY).

\section{Introduction}

Flooding is the natural hazard that historically has had the highest costs in terms of both economic impact and human deaths (Berz et al., 2001). Using the Emergency Events Database (http://www.emdat.be), de Brito and Evers (2016) concluded that between 2000 and 2014, floods were the most frequent natural disaster world- wide causing at least 85,000 fatalities, which had an impact on the wellbeing of about 1.4 billion people, and were associated with a total cost equivalent to USD 400 billion in damage.

Among the different types of floods, e.g., coastal sea and pluvial floods, this article will focus on urban river floods, as rivers are key features of many urban areas around the world. This is a major problem especially in 
coastal lowlands (Eldho et al., 2018). Cities and mega urban agglomerations that occupy delta landscapes typically become increasingly flood prone due to the multiple processes of climate-change driven flow-frequency changes, sea-level rise, and subsidence of land when upstream dams are hindering sediment transport and wetlands are converted to urban land (Bren d'Amour et al., 2017; Syvitski et al., 2009). While urban flooding cannot be entirely prevented, the losses that have occurred could be dealt with by planning authorities applying different flood risk management strategies such as flood risk prevention, flood defense, flood risk mitigation, flood preparation, and flood recovery (Hegger et al., 2016).

The vicinity of rivers has historically been attractive for urban development (Montz, 2000), as they provide transport possibilities, food, water for drinking and for irrigation, as well as numerous kinds of cultural ecosystem services, among other benefits. Between 1960 and 2017, global urbanization increased the number of urbanites from 1 to 4 billion (Ritchie \& Roser, 2018), where a large part of the increase has taken place on river floodplains (Du et al., 2018). Besides changes as precipitation patterns and development practices, over time this has led to a greater share of the global population becoming increasingly exposed to floods (Głosińska, 2014). As the effects of river floods are well known and a variety of solutions of both technical and strategic nature are available, solving the river flood problem may sound like an easy task. However, history has shown that the human practice of building in low-lying floodplains or close to rivers is not easy to change. Although previous research does discuss how the risk of flooding can be better tackled, researchers have demonstrated that in many parts of the world material damage and death tolls caused by river floods continue to be high (Kundzewicz et al., 2018).

Human-induced global warming has taken place during the last 50 years (Intergovernmental Panel on Climate Change [IPCC], 2018). This climate change is often thought to equal warmer weather and greater risks of forest fires or increased sea levels due to glacier melting and thermal expansion of sea water. However, due to changing patterns of the weather systems or changes in the snow-melt cycles, the effects may as well bring increased rates of rainfall and surface runoff. Predicted future climate change will lead to changed river flow frequencies, which means that the 100-year flood will be smaller in some rivers, but larger in others, for instance (Arheimer \& Lindström, 2015). Hence, there is great underlying uncertainty of what the future will bring in terms of magnitude of flood flows, as well as an uncertainty inherent in numerical flood risk modeling and mapping procedures (e.g., Merwade et al., 2008).

Previously, much of the urban research has focused on the sustainability of urban development. Around the turn of the last millennium, parts of this research began focusing on resilience (cf. Meerow et al., 2016).
An early treatise of urban resilience and hazards in general was written by Godschalk (2003) with the aim to start resilient cities initiatives. Since then, attention has been paid particularly to flood hazards resilience. Liao (2012) puts forward how the resilience concept can be used to overcome the conventional view that cities need flood control as the only flood management tool, and instead adhere to flood adaptation strategies. Similar reasoning is found in Wenger (2017), who found evidence of a shift from structural mitigation and levee dependency to support for alternatives such as ecosystembased measures and development relocation. Bergsma (2017) further argues that the traditional hard engineering kind of solutions should be complemented with local-oriented spatial planning expertise. Although the hydraulic models have proved very valuable in many cases, there is plenty of evidence that they and their related flood risk maps are uncertain; from model input, over model structure and parameterization, to model output (Di Baldassarre \& Montanari, 2009; Lim \& Brandt, 2019a). Similarly, Meerow et al. (2016) found evidence of an increase in academic resilience research, especially with respect to climate change, that uncertainty and risk were acknowledged as potential drivers for creating urban resilience. Therefore, drawing on Bertilsson et al. (2019), who point out that an intelligent urban drainage design used together with emerging resilience approaches may be an interesting way forward, we conclude that there may be new approaches that can go beyond and increase the benefits of these hydraulic models in relation to spatial planning and resilience. As it is obvious that urban planners cannot any longer ignore risks associated with urban floods, neither should they ignore the uncertainties related to flooding.

Most of today's urban areas have been developed in a climate different than what is expected in a near future, with only relatively limited considerations that climate change will impact both the magnitudes and the frequencies of river floods. We therefore argue herein that to benefit resilience thinking, current practices in urban planning need to be expanded, for example by developing new software tools. Our present and future urban management and development plans need not only to consider the uncertainty related to the wider effects of climate change, but also the uncertainty related to potential local impacts (Meerow \& Woodruff, 2020). However, in practice, uncertainty is often seen as something difficult to deal with and often leads to maladaptive planning (Moroni \& Chiffi, in press; Pappenberger \& Beven, 2006). Hence, in this article an attempt will be made to propose a tool that can help using uncertainty as a leverage, or as a management opportunity, which together with resilience thinking may increase the chances of creating not only flood-resilient urban environments, but also resilient cities in a more general sense.

The aim of this article is therefore to increase the opportunities of reducing flood risks by using uncertainty as an argument and a tool to create more resilient urban 
areas. If this takes place, a number of other positive effects are then also possible, such as higher quality of urban ecosystem services for human wellbeing. In pursuit of this aim, the objectives of the article are: 1 ) to present a prototype flood-inundation mapping tool that creates a buffer zone of varying width around a river based on uncertainties associated with the digital elevation model (DEM) and land cover roughness; and 2) to discuss how this tool can benefit resilience thinking in urban planning.

\section{Previous Research on Urban Resilience With Respect to Floods}

\subsection{Urban Resilience}

The concept of resilience can be traced back to Holling's $(1973,1986)$ works. He defined resilience as "the ability of a system to maintain its structure and patterns of behavior in the face of disturbance"; something that is connected to, but different from, stability, which "emphasizes equilibrium, low variability, and resistance to and absorption of change" (Holling, 1986, pp. 296-297; cf. Folke et al., 2003, and Marchese et al., 2018, for a thorough treatise on the sustainability and resilience concepts). Meerow et al. (2016, p. 45) further add that urban resilience needs the ability "to adapt to change, and to quickly transform systems that limit current or future adaptive capacity." From there, one definition has emerged that particularly focuses on resilience to natural disasters, viz. "the ability to prepare and plan for, absorb, recover from, and more successfully adapt to adverse events" (National Research Council, 2012, p. 1), which is particularly relevant for the topic of this article. Resilience thinking has therefore become a fundamental framework for understanding complex adaptive systems, from ecosystems to cities and cells and to economic systems (Levin, 1999). In ecology, the concept of resilience describes the capacity of an ecosystem to absorb disturbance and reorganize while undergoing change so as to retain essentially the same function, structure, identity, and feedbacks (Holling, 1973). Central for an understanding of resilience thinking is an understanding of what role disturbance plays for system renewal over space and time (Colding et al., 2003). Disturbances such as fires, heavy storms, and floods are considered to be a natural part of the development of many ecosystems, and the renewal capacity of ecosystems depends on natural perturbations (Holling, 1986); the trick is to make sure that the intensity, duration, and periodicity of a particular disturbance are not too high, long-lasting, and too frequent in order to avoid making them unmanageable (Connell, 1978).

Many human communities adapt to and even depend on flooding for their survival, such as for irrigation and fertilization of food cultivars and crops (Colding et al., 2003). The knowledge gained of flood management practices that promote resilience have enabled some communities to adapt to floods and their conse- quences and even taking advantage of this process. This is indicative of that the perception of disturbance as a risk also can be seen as a cultural phenomenon, where frequent natural disturbances force local-level management practices into action (Colding et al., 2003). This is in line with Zevenbergen et al. (2020), who argue that resilience in flood risk management entails that societies should learn to live with floods and not seek to entirely avoid them. However, flooding is commonly perceived as a nuisance in many societies, and decision makers often seek to command and control it in an attempt to entirely prevent the disturbance. Therefore, flood defense provides a key resilience strategy with the aim to reduce the probability of flooded areas through infrastructural measures such as through dikes, dams, and different kinds of embankments (Hegger et al., 2016). Such design and operation flood-control measures of flood resilient technologies have proven valuable (Zevenbergen et al., 2020), but engineering resilience measures risk altering natural disturbance regimes in such a way that pulse events are transformed into persistent disturbance or even chronic stresses (Nyström et al., 2000). Engineering resilience also presumes that the system remains constant over time, disregarding the fact that extreme disturbance events may have profound impacts on the system's functioning (Zevenbergen et al., 2020).

Social-ecological resilience involves the interaction between human societies and natural systems. Such resilience in a flood risk management context calls for an adaptive approach in recognition of that conditions change over space and time. Adaptability refers to human actions for sustaining critical functions on which humans depend and is a process of deliberate change in anticipation to external stresses (Folke, 2016). The adaptability concept in resilience thinking therefore captures "the capacity of people in a social-ecological system to learn, combine experience and knowledge, innovate, and adjust responses and institutions to changing external drivers and internal processes" (Folke, 2016, p. 44). By virtue of technological sophistication and the opportunity of advanced nations to invest in costly exogenous inputs, flood risk management in urban areas may be imperiled by focusing too narrowly on flood control by way of the construction of levees. It risks neglecting aspects such as coordinated investment in flood retaining activities and allowing seasonal flooding of catchment by, for example, providing compensation to land use that may dampen flood peaks (Johannessen, 2015). Abandoning building schemes entirely in flood-prone land may therefore be a sensible urban planning strategy. Findings by Lewis et al. (2017) in relation to resilience management following the catastrophic flooding during Hurricane Katrina in 2005 indicate that resettlement and landscape management policies such as flood risk prevention are important resilience measures. For boosting the adaptive capacity in social-ecological systems, Folke et al. (2003) therefore proposed four key features of socialecological resilience-building; these include: learning to 
live with change and uncertainty, nurturing diversity for reorganization and renewal, combining different types of knowledge for learning, and creating opportunity for selforganization toward social-ecological sustainability.

Knowledge building is integral to strengthening resilience among people by informing them of the risks involved in flooding through a risk communication process. The imparted information during risk communication forms an important component of the knowledge base when dealing with hazards and risks, as it allows the general public, communities, organizations, and decision-makers to better comprehend risk, and to plan and take actions that can reduce costly consequences of flood disasters (cf. Lewis \& Ernstson, 2019).

\subsection{Natural Hazard Risk Communication}

Risk communication is a significant part of the risk management process to cope with natural hazards, mitigate risks and impacts of disasters, as well as to reduce vulnerabilities. At the same time, it helps planners and decisionmakers generate strategies that can be adopted to make communities sustainable and resilient (Pine, 2015). One of the important roles of risk communication in disaster mitigation is raising people's awareness about their exposure and vulnerability to a certain hazard, and informing them of how they can protect themselves in case the risks materializes into a disaster (Dransch et al., 2010).

Flood hazard and risk maps are the most common tools used in flood risk communication processes. Mapping as a whole provides a framework for examining, determining, and visualizing areas that are under potential threats of a natural hazard (Pine, 2015). Within the flood risk management context, risk communication aims to prepare people for the possibility of floods, so as to reduce the possible flood impacts to them (Rollason et al., 2018), thereby promoting resilient behaviors in terms of preparedness. Hazard maps visualize the geographical extents, depths, or velocities of floods at a given risk probability, while risk maps combine the former with the possible economic, social, environmental, or cultural consequences of flooding (van Alphen et al., 2009), i.e., taking into account the hazard and vulnerabilities as it visualizes the scale of the risk.

Recently, the focus on flood risk communication through maps has shifted to flood uncertainty mapping and visualization, as it is recognized by several researchers that there will always be associated uncertainties in flood maps. According to Pang et al. (1997), the main purpose of visualizing uncertainties is to mediate information inaccuracies, so as to increase understanding of the information and its limitations, as well as to facilitate decisions. In flood modeling, there are different approaches in quantifying uncertainties (cf. Section 2.3) and showing them on maps. Monte Carlo simulation results, for instance, where model inputs are varied to produce different outputs, are often weighted and aggregated into a single map, visualized as fuzzy information indicating the probability of the flood (Di Baldassarre et al., 2010) or the degree of uncertainty present in the flood map (Horritt, 2006). Results from fewer simulations are shown by overlaying different results to see how the flooding extents vary as effect of, for example, the resolution, Manning's roughness, or the model used (Lim \& Brandt, 2019b). Using a multiple map display to show the various flood maps generated for each modeling is an alternative visualization method if visual overlay is impossible (Horritt, 2006; Lim \& Brandt, 2019b; Saksena \& Merwade, 2015). Hence, flood uncertainty communication through maps can help improve knowledge of the possible miscalculations of risks associated with flooding, by being able to recognize the limitations of the presented information. Such acknowledgement of the inevitability of uncertainty in flood maps due to the unpredictability of the flood event allows an adaptive way of dealing with the unknowns, which is an important concept in resilience, and in increasing adaptive capacity (Restemeyer et al., 2018). Furthermore, as Thorne et al. (2018) highlight, to really increase the implementation of blue-green infrastructure and sustainable flood risk management, not only biophysical but also social dimensions and political values need to be identified and managed in the communication process.

\subsection{River Flood Modeling and Inherent Uncertainties}

All models include weaknesses and flaws to different degrees, hydraulic models being no exceptions. Even though new research findings and more powerful computers have improved the models over the years, their results are still uncertain. Those uncertainties may arise from a variety of sources. Input data uncertainties depend on the raw-data acquisition instrument's accuracy and the processing methods that precedes the hydraulic modeling. Hydraulic models require topographic data, in the forms of DEMs or cross sections (CS), to derive the elevation values used in the models' equations. Uncertainties in model results as effect of topographic data are often caused by the DEM's quality (Lim \& Brandt, 2019b; Saksena \& Merwade, 2015), the geometric configuration of the CS (Cook \& Merwade, 2009), and the inclusion of buildings and other structures in the DEM (Koivumäki et al., 2010) or unforeseen events such as dike and levee breaks (Apel et al., 2008; Ranzi et al., 2013). Hydrologic data are used for deriving rating curves, hydrographs, water stages, and depths that are used as input boundary conditions in the model. Errors in these can cause errors in the initial discharges/depths, which in turn cause uncertainties in flow calculations in the modeling (Di Baldassarre \& Montanari, 2009). Uncertainties in the model are for example affected by approximations made in the equations applied to reduce computational complexities. Thus, different models can produce different results (Hunter et al., 2008). Finally, there is parameter uncertainty, of which the roughness coefficient is the most important and to which hydraulic 
models are highly sensitive (Lim \& Brandt, 2019b). It is often expressed by the Manning's $n$-value, which is a measure of the frictional resistance the water experiences when it flows over channel bed and land. The resistance varies according to bed material grain sizes, type and amount of vegetation, presence of bedforms, sinuosity of the river, and so forth. It is usually assigned based on land cover type and recommended values in literature. However, its true value is never known, unless tested at the specific study site. Furthermore, the roughness also interacts with the DEM resolution, the boundary conditions and the discharge used, making its value difficult to determine.

All sources of uncertainties affect the calculated flow and hence also the extent of the inundation. How these uncertainties are dealt with varies. There are both deterministic and probabilistic approaches available (Beven, 2009; Di Baldassarre et al., 2010), where a common way to understand, estimate, or even reduce the degree of uncertainty is by performing a sensitivity analysis (Pappenberger et al., 2008). With respect to impact on the positional quality of the modeled flood boundary, the estimation of channel bed and floodplain roughness together with the quality of the DEM stand out as crucial for successful modeling (Lim \& Brandt, 2019a, 2019b; Saksena \& Merwade, 2015). Roughness estimation is usually handled through calibration, so that modeled flood boundaries match field observations as close as possible, and by varying the roughness, uncertainty estimates can be derived. The quality of the DEM, on the other hand, is not that easy to vary. There is consensus that high-resolution DEMs provide the best input for hydraulic modeling, and that if lower resolution DEMs are used, the uncertainty of the flood predictions correspondingly increases. However, besides resolution, the terrain slope also affects the uncertainty, as flat areas produce more uncertain results than steeper ones. But the slope depends not only on the DEM's cell distance; it is also related to the quality of each measured elevation point in the input data. This quality and estimated uncertainty heavily depends on land cover type, the sensor quality, and the distance between the sensor and the ground. Hence, simulating different quality of DEMs makes modeling significantly more difficult and time consuming compared with simulating roughness variation, where the roughness value can be changed easily for large geographical areas. Klang and Klang's (2009) study, simulating different airplane altitudes of Lidar data gathering, clearly shows the complexity of producing such DEMs. The next stage in uncertainty estimation would then involve using each DEM in the hydraulic modeling process to add further uncertainties. Due to the amount of work required to produce DEMs of truly different qualities, the normal approach to handle DEM uncertainty is to equate it with cell resolution. To overcome this uncertainty estimation problem, Brandt (2016) used Klang and Klang's (2009) DEMs and developed an empirical equation for one-dimensional (1D) flood models, where the disparity distance between modeled and true flood boundary is a function of the perpendicular terrain slope, the DEM resolution, and the percentile of interest (i.e., confidence level). Using this approach, it is then possible to produce uncertainty zones on both sides of the originally modeled crisp flood boundary line without needing to first create several DEMs of different qualities.

\section{Development of a GIS Tool to Create Uncertainty Zones Around Modeled Flood Boundaries}

\subsection{Disparity Distance $\left(D_{d}\right)$ Algorithm}

Brandt's (2016) algorithm (cf. Brandt \& Lim, 2016; Lim, 2018) creates uncertainty zones around predicted flood boundaries from 1D hydraulic simulations. Whereas uncertainty zones usually are produced by probabilistic models (Merwade et al., 2008), disregarding the terrain slopes, the uncertainty zones here are based on the characteristics and quality of the used DEM. The algorithm's main assumptions are: 1 ) the disparity between model and reference data increases as the slope values decreases (and vice versa); and 2) lowering the DEM's resolution further increases this disparity. Thus, the disparity becomes a function of the slope perpendicular to the flow $(S)$, DEM resolution $(\delta)$, and the level of confidence used for the uncertainty assessment ( $P$; Equation 1).

$$
D_{d}=\left[\delta^{0.970} 0.000792 P^{1.303}\right] S^{[0.1124 \ln (\delta)+0.0709 \ln (P)-1.0064]}
$$

Data needed for the algorithm are the modeled flooded area, a DEM in Triangular Irregular Network (TIN) format, and CS. The TIN and CS are used to generate sampling nodes, while CS and flood boundary produce water surface elevation (WSE) points (Figure 1).

The algorithm proceeds iteratively, node-by-node, for every CS and part (left or right) of the channel. It starts by computing the slope and distance between a given sampled node and the WSE point (i.e., where the CS intersects the flood boundary). $D_{d}$ is then calculated and evaluated if it exceeds the actual distance. When exceeded, the computation stops at this node. The node's elevation information is recorded as the inner or outer (i.e., on the channel or land side of the modeled flood boundary, respectively) uncertain height value for that CS and channel part, and these are assigned to the sampled nodes. These uncertain elevation values are afterwards used to generate one inner and one outer uncertain elevation TIN, which are compared with the original DEM to identify flooded, uncertain, and non-flooded areas (Figure 2).

\subsection{Tool Development}

The geographical information system (GIS) tool for delineating uncertainty zones around a modeled flood boundary was created with ArcGIS model builder and Python scripting language. The tool consists of two parts: 1) 


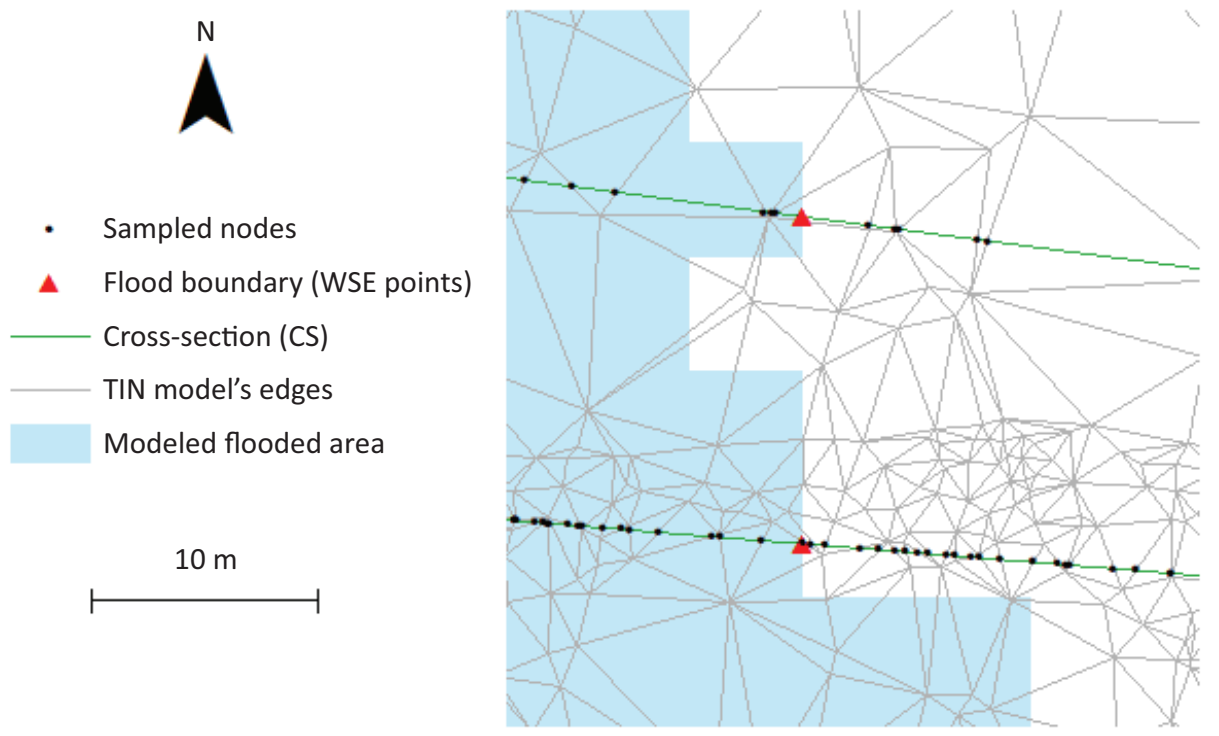

Figure 1. Sampled nodes (black points) are derived by intersecting the TIN model's edges and the CS. WSE points (red triangles) are derived where the flood boundary intersects the CS.

preparation of the data to be used for the algorithm (Figure 3); and 2) implementation of the uncertainty algorithm and mapping (Figure 4). In the preparation part, the flood boundary result from a previous 1D hydraulic simulation, the CS data with the WSE information, stream centerline, flowpaths, and a TIN elevation model are preprocessed. These are used to derive points at the flood boundaries intersecting each CS (i.e., WSE points), and sampling nodes from the CS intersecting the TIN model's edges (Figure 1). Each node is identified with the CS number, its part location (left or right) in the main channel, as well as if it is inside or outside the flood boundary, using the stream centerline and flowpaths datasets. The $x, y$ coordinates and the height $(H)$ information derived from both datasets are used to compute the distance $(D$, Eq. 1 in Figure 3$)$, slope $(S$, Eq. 2$)$, coefficient $c$ and exponent $z$ (Eqs. 3 and 4, derived from the resolution $[\delta]$ and percentile $[P])$, and the disparity distance $\left(D_{d}\right.$, Eq. 5$)$ between the given node and WSE point. The status of each node is evaluated whether it is flooded, dry, or uncertain. Afterwards, all nodes are grouped per CS, part and side, and sorted according to

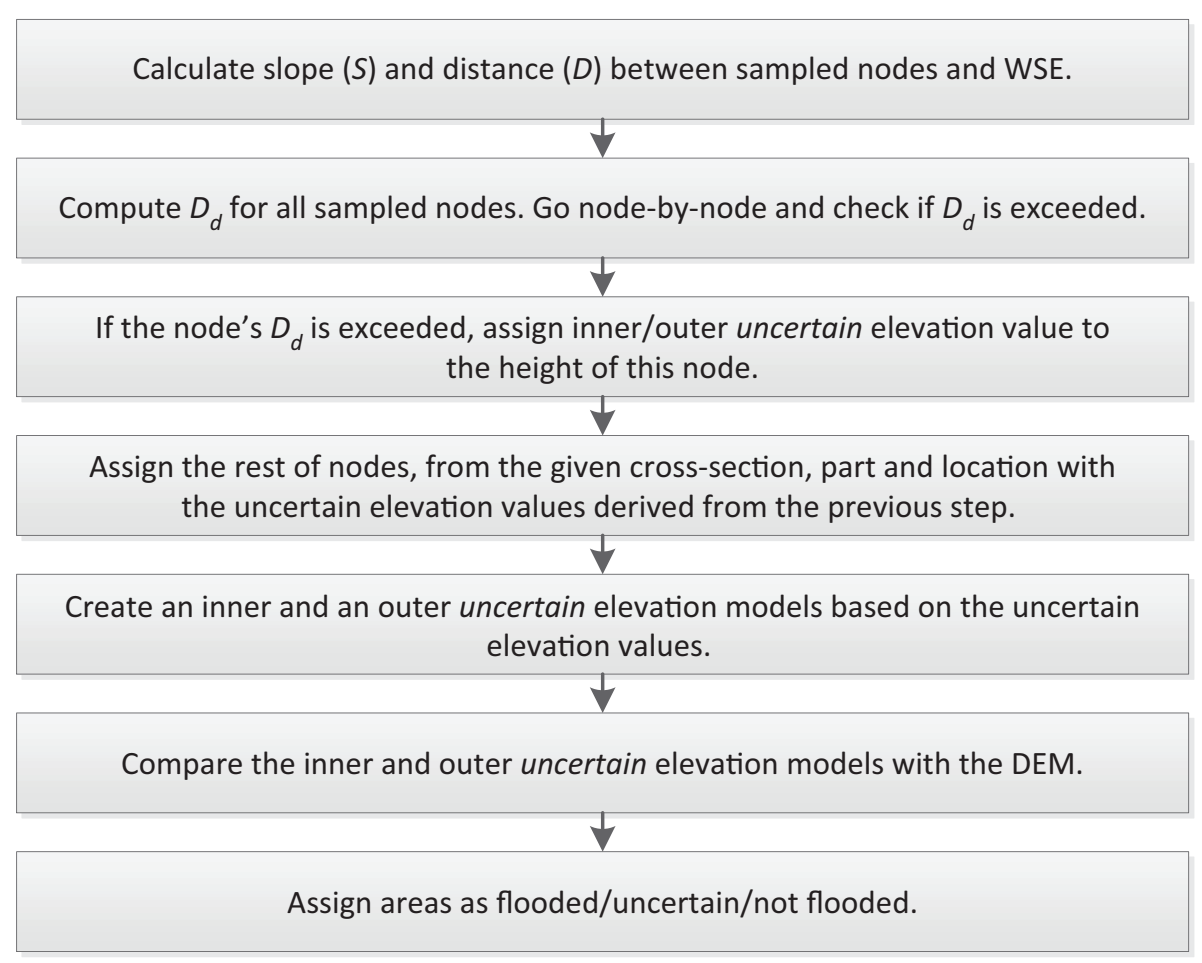

Figure 2. A simplified workflow of the $D_{d}$ algorithm by Brandt (2016). 
distance. Tables are then created and named based on the groupings. Prior to the implementation of the algorithm, two empty tables that contain the computed outer and inner uncertain height values are created.

The algorithm (Figure 4) starts with the table containing nodes from the first CS's left part and outer side. It begins the row iteration with the node having the closest distance from the WSE point. If the status of this node is uncertain, and the next adjacent node $(k+1)$ has certain status, the algorithm gets the entire row information for the next node $(k+1)$ with the certain status and append this on the outer uncertain height table. This initially represents the outer uncertain elevation value for the specific CS and part. Otherwise, the iteration continues to the next row, until the condition is met. The algorithm then proceeds to the next table containing nodes in the inner side of the same CS and part. When the algorithm has finished appending the preliminary inner and outer uncertain elevation values in the tables representing all $\mathrm{CS}$, the height $(H)$ information of the nodes is assessed for wall effect, using Eq. 6 for all outer nodes, and Eq. 7 for all inner nodes. If $H_{\text {out }}<H$ and $H_{\text {in }}>H$, then the $H_{\text {out }}$ and $H_{\text {in }}$ values are assigned to the node, otherwise, the $H$ of the node is used.

The computed uncertainty information is then joined with the original nodes data based on the CS and part ID. These new elevation values are used to create TIN models representing the water surface of inner and outer uncertainty limits. The created TINs are subtracted from the original TIN elevation model to determine whether the ground is flooded, uncertain, or not flooded. This is done through an overlay of polygons representing these areas.

\section{Using Uncertainty Zones as a Resilience Tool}

\subsection{Study Area, Data, and Hydraulic Model Used}

Earlier flood modeling results by Lim (2011) were used to test the tool. The study area is located along the Testebo river, in the northern parts of the city of Gävle, Sweden. The area consists of arable and pasture lands with surrounding residential areas, some which are relatively frequently flooded. The entire river is about $85 \mathrm{~km}$ long,

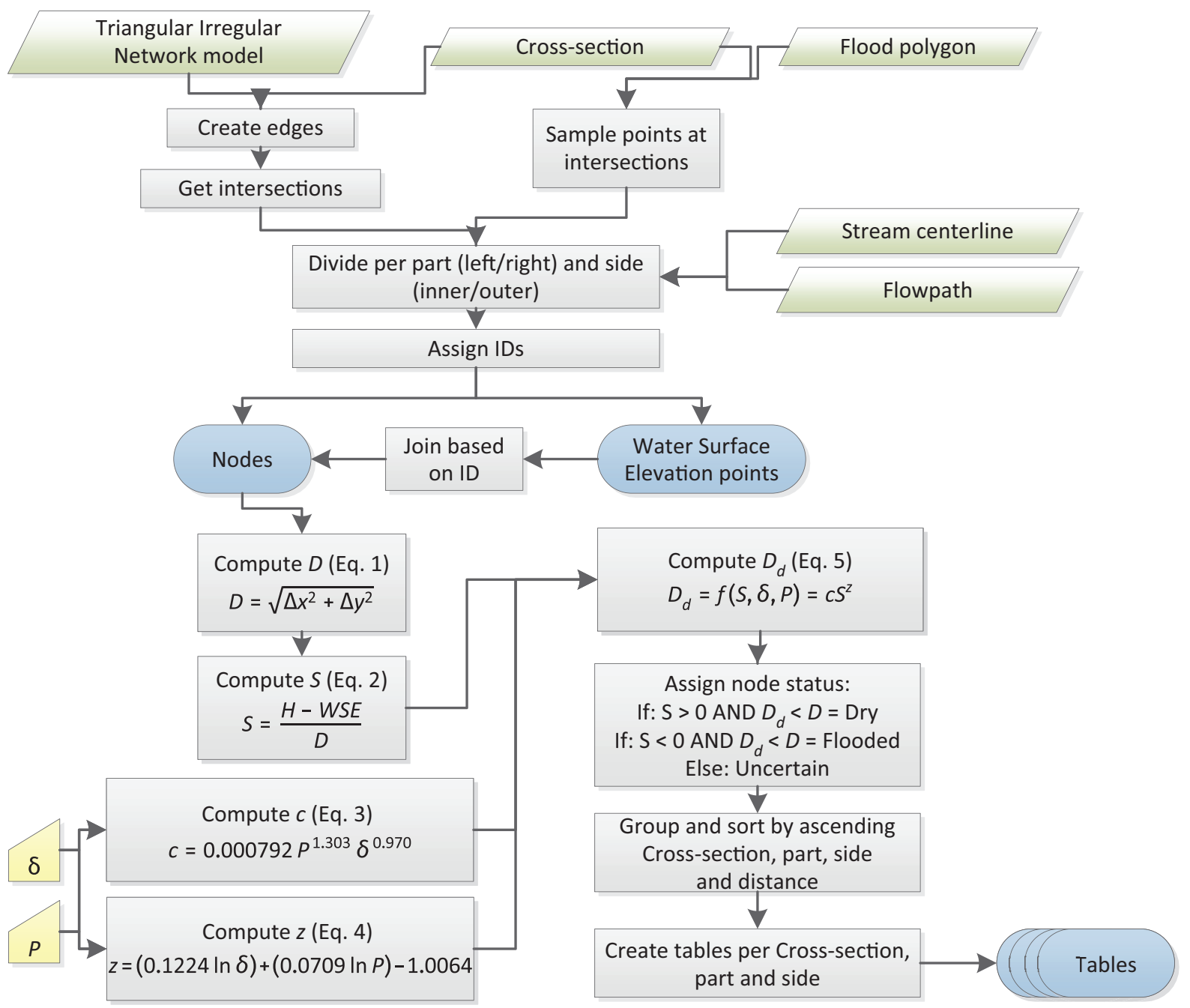

Figure 3. Workflow for preparing data and tables used in the algorithm. Main inputs are: modeled flooded area, TIN model representing the topography, and CS, stream centerline, and flowpath used in the hydraulic simulation. 


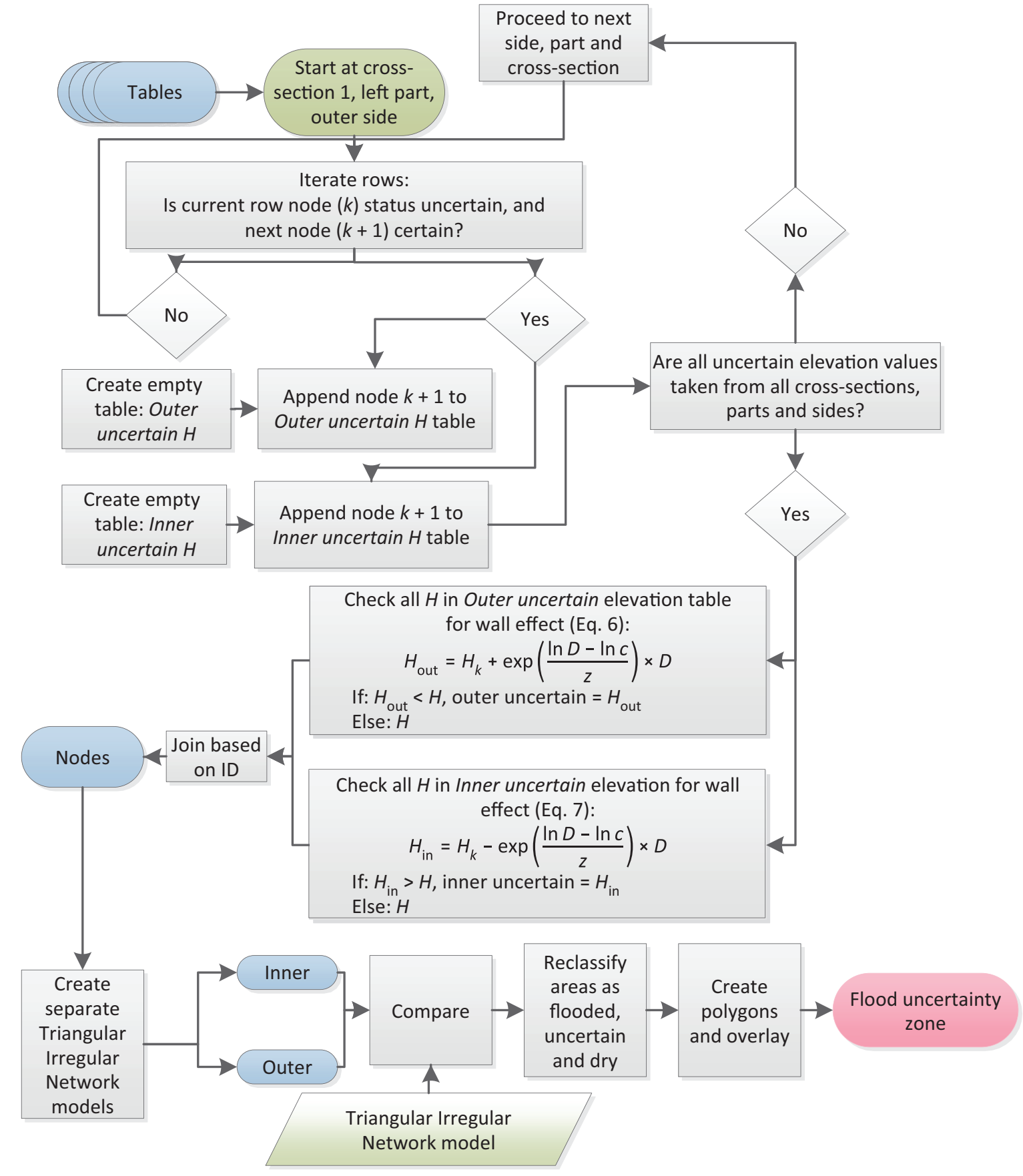

Figure 4. Implementation of the algorithm and generation of the uncertainty zone.

stretching from Åmot in Ockelbo municipality southeast to Gävle, and has a mean annual discharge of $12.1 \mathrm{~m}^{3} / \mathrm{s}$.

The 1D HEC-RAS steady-flow model (Hydrologic Engineering Center, 2008, 2010) was used for the hydraulic simulations. That means discharge, velocity and depth all are constant at each CS. 1D models also consider flows to be unidirectional (parallel to the channel). The topographic data used for the modeling were produced by combining point cloud Lidar data $(2.1 \mathrm{~m}$ resolution) with bathymetric data into a TIN. The water discharge used was $160 \mathrm{~m}^{3} / \mathrm{s}$, corresponding to the big flood event in 1977. Lim's study ran 500 combinations of channel (ch) and floodplain ( $\mathrm{fp}$ ) Manning's $n$ in a Monte Carlo simulation to produce multiple flood maps (Lim, 2011). Two of the results used low $\left(n_{\mathrm{fl}}=0.030\right.$ and $\left.n_{\mathrm{ch}}=0.026\right)$ and high $\left(n_{\mathrm{fl}}=0.098\right.$ and $\left.n_{\mathrm{ch}}=0.049\right)$ Manning's $n$, which were used as input data for the new GIS tool. These results were then rasterized using a cell size of $5 \mathrm{~m}$.

\subsection{Testing the Resilience Tool}

The uncertainty zone produced by the new GIS tool is based solely on the quality of the DEM and the terrain slope characteristics. The previous study by Brandt and Lim (2016) shows, however, that the true flooded area sometimes may be considerably outside or inside 
this uncertainty zone. To enable capturing some of this additional uncertainty, it seems most relevant to include an estimate of roughness uncertainty. Results produced by the 1D hydraulic model with low Manning's $n$ generate smaller flood areas, which are often underpredicted, whereas high Manning's roughness produces bigger inundation areas that overestimate the flooding. Therefore, a wider uncertainty zone can be created by executing two runs in the hydraulic model, one with minimum and one with maximum estimated roughness, respectively, and feeding these into the new GIS tool. The inner uncertainty boundary is then produced from the low-roughness model, while the outer boundary comes from the high-roughness model (Figure 5).

By combining the uncertainty of roughness, quality of DEM, and terrain slope, the probability of encapsulating true flood boundaries within the modeled extended uncertainty zone increases. As urban planning needs to consider the spatial extent and variation of the rivers, which can be directly linked to the uncertainty zone output of the new tool, there is an opportunity not only to link this uncertainty directly to resilience management and approaches (cf. Ashley et al., 2020), but also to facilitate resilience thinking and communication.

\section{Discussion and Conclusion}

New insights in urban sustainability and resilience have caught the interest of researchers to use the risk of nat- ural hazards as a driver and opportunity to promote resilience thinking and management. Hence, a GIS tool that emphasizes uncertainty in flood modeling has been developed to advance such use of risk (i.e., comprising the probability of an adverse event) further. During the planning process, areas next to a river that are considered as threatened to be flooded are usually visualized as buffer zones of fixed width or having risk up to a certain WSE. Very rarely, due to their complexity and difficulty to perform, probabilistic models of flood risks are used. However, those models never include the terrain variation (slope characteristics) to our knowledge. By using Brandt's (2016) algorithm, though, it is possible to incorporate both the quality of the DEM and the terrain slope for estimating the uncertainty. The tool runs in the ArcGIS environment and works with new or already existing hydraulic model results to create uncertainty zones of varied width around a modeled flood boundary. One specific advantage of the tool is that it does not require extensive knowledge in GIS and hydraulic modeling. Another is that it will work for both rural and urban environments, provided the hydraulic modeling as such can be justified. By running the tool twice, for hydraulic model runs of low and high bed roughness, respectively, the tool will produce uncertainty zones that are wide enough to capture most of the uncertainty of the modeled flood's spatial extent. If the modeler wants to have extra uncertainty, the preceding hydraulic model can be run in a 'what if' mode, i.e., by including

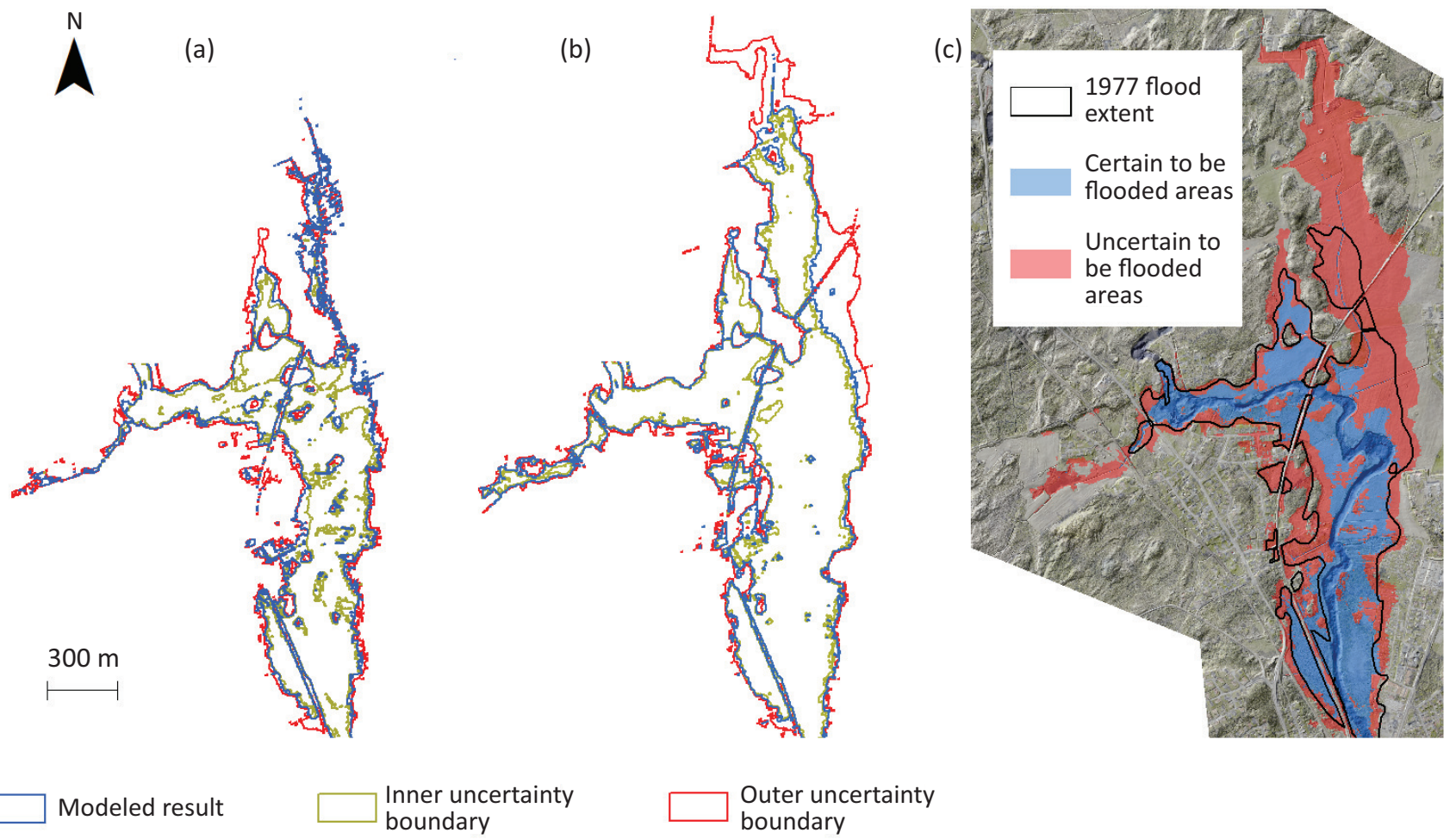

Figure 5. Example of model results for the Testebo river produced by the new GIS-tool. (a) Uncertainty zones from low-roughness 1D model; (b) uncertainty zones from high-roughness 1D model; and (c) resulting increased uncertainty zone serving as a resilience zone. 
variations of infrastructure or possible levee breakages. However, there is the tradeoff that with larger uncertainty zones municipalities may be prevented from maximizing land utilization in areas with low risk probability, which could lead to loss of revenues. Nevertheless, with the uncertainties in magnitudes and frequency of huge flood events, it still remains a possibility that these low-risk areas will be flooded in the future. Thus, urban planners can use the tool's result not only for discussing resilience; it should also resort to ways on how they can utilize the extended uncertainty zones to projects that are resilient and adaptive to flooding consequences, especially with respect to climate change. We argue that whether the uncertainty is modeled with high precision is not the most important factor, but rather whether blue-green areas are included to a sufficient degree in the uncertainty zones generated. They can then function as proper and valuable resilience measures, not only for urban planning and management processes, but also for floodplain ordinances.

Despite alarming reports by the IPCC about heightened intensity and frequency of storms and flooding (IPCC, 2014), many urban areas are still planned as if climate change does not occur. Making decision-makers understand that climate change has and will have consequences is a huge challenge. Often planners completely rely on existing engineering solutions, which to a large extent ignore the natural variation of earth surface processes and climate change, and see the riverine environment just as an attractive zone to build new houses. Further, as maps are generally used as deterministic background documents, we believe there is a need to visualize zones of uncertainty in maps. These should be used both for policies and solutions that mitigate risk, and simultaneously should aim to provide citizens with a plurality of ecosystem services for human wellbeing. Hence, such zones of uncertainty in maps concurrently provide decision-makers with tools to put precautionary principles in action in urban governance processes. One reason for this not taking place is probably related to the fact that decision makers and the public often lack knowledge and confidence that blue-green infrastructure is vital for building resilience towards climate change impacts (Thorne et al., 2018). Most people now, however, do realize the negative consequences of extreme floods, and that they might be affected in the future. This makes the concept of uncertainty a promising tool for resilience planning of urban areas. If there is a risk involved, and the size of the area at risk is uncertain, there should be a fair chance during the planning process that urban planners and decision makers consider not only the originally modeled extent of a flood event, but also include an extended area. Reserving and protecting such areas from undesired urban development will automatically provide necessary resilience-rooms for the dynamic rivers. By doing so, there will be a number of positive side effects. In addition to a decrease of the negative consequences of flooding, there will also be easier access to the river and strengthening of legal rights of public access for shoreline areas, which simultaneously may hold richer levels of biodiversity. Uncertainty, as a planning approach, would enable green city designs and opportunities for a number of ecosystem services, such as flood-dependent agroforestry, and higher possibility of yielding cultural ecosystem services that promote people's health. As the UN prospects urban landscapes for another 2.5 billion people in 2050, amidst oncoming climate change (UN-Habitat, 2016, p. 38), new tools for urban resilience planning are therefore urgently needed. Such tools partly need to embrace uncertainty as a strategy for dealing with flooding.

\section{Acknowledgments}

This work was partly funded by Future Position $X$ through its project Bettering life through integrative GIS (BIG) which aims to co-create knowledge for urban solutions on how healthy, sustainable, and livable cities should be built in the future. Thanks are due to the four anonymous reviewers who provided very valuable and constructive feedback on the article.

\section{Conflict of Interests}

The authors declare no conflict of interests.

\section{References}

Apel, H., Merz, B., \& Thieken, A. H. (2008). Quantification of uncertainties in flood risk assessments. International Journal of River Basin Management, 6(2), 149-162. https://doi.org/10.1080/15715124. 2008.9635344

Arheimer, B., \& Lindström, G. (2015). Climate impact on floods: Changes in high flows in Sweden in the past and the future (1911-2100). Hydrology and Earth System Sciences, 19(2), 771-784. https://doi.org/ 10.5194/hess-19-771-2015

Ashley, R., Gersonius, B., \& Horton, B. (2020). Managing flooding: From a problem to an opportunity. Philosophical Transactions of the Royal Society A: Mathematical, Physical and Engineering Sciences, 378(2168), Article 20190214. https://doi.org/ 10.1098/rsta.2019.0214

Bergsma, E. J. (2017). From flood safety to risk management: The rise and demise of engineers in the Netherlands and the United States? [Doctoral dissertation, University of Amsterdam]. Library Wageningen University \& Research. https://library.wur.nl/ WebQuery/hydrotheek/2280469

Bertilsson, L., Wiklund, K., de Moura Tebaldi, I., Moura Rezende, O., Pires Veról, A., \& Gomes Miguez, M. (2019). Urban flood resilience-A multi-criteria index to integrate flood resilience into urban planning. Journal of Hydrology, 573, 970-982. https://doi.org/ 10.1016/j.jhydrol.2018.06.052 
Berz, G., Kron, W., Loster, T., Rausch, J., Schimetschek, J., Schmieder, J., Siebert, A., Smolka, A., \& Wirtz, A. (2001). World map of natural hazards-A global view of the distribution and intensity of significant exposures. Natural Hazards, 23(2/3), 443-465. https:// doi.org/10.1023/A:1011193724026

Beven, K. (2009). Environmental modeling: An uncertain future? Routledge.

Brandt, S. A. (2016). Modeling and visualizing uncertainties of flood boundary delineation: Algorithm for slope and DEM resolution dependencies of 1D hydraulic models. Stochastic Environmental Research and Risk Assessment, 30(6), 1677-1690. https://doi. org/10.1007/s00477-016-1212-z

Brandt, S. A., \& Lim, N. J. (2016). Visualising DEMrelated flood-map uncertainties using a disparitydistance equation algorithm. Proceedings of the IAHS, 373, 153-159. https://doi.org/10.5194/piahs373-153-2016

Bren d'Amour, C., Reitsma, F., Baiocchi, G., Barthel, S., Güneralp, B., Erb, K.-H., Haberl, H., Creutzig, F., \& Seto, K. C. (2017). Future urban land expansion and implications for global croplands. Proceedings of the National Academy of Sciences, 114(34), 8939-8944. https://doi.org/10.1073/pnas.1606036114

Colding, J., Elmqvist, T., \& Olsson, P. (2003). Living with disturbance: Building resilience in socialecological systems. In F. Berkes, J. Colding, \& C. Folke (Eds.), Navigating social-ecological systems: Building resilience for complexity and change (pp. 163-185). Cambridge University Press. https://doi. org/10.1017/CBO9780511541957.011

Connell, J. H. (1978). Diversity in tropical rain forests and coral reefs. Science, 199(4335), 1302-1310. https:// doi.org/10.1126/science.199.4335.1302

Cook, A., \& Merwade, V. (2009). Effect of topographic data, geometric configuration and modeling approach on flood inundation mapping. Journal of Hydrology, 377(1/2), 131-142. https://doi.org/ 10.1016/j.jhydrol.2009.08.015

de Brito, M. M., \& Evers, M. (2016). Multi-criteria decision-making for flood risk management: A survey of the current state of the art. Natural Hazards and Earth System Sciences, 16(4), 1019-1033. https://doi. org/10.5194/nhess-16-1019-2016

Di Baldassarre, G., \& Montanari, A. (2009). Uncertainty in river discharge observations: A quantitative analysis. Hydrology and Earth System Sciences, 13(6), 913-921. https://doi.org/10.5194/hess-13-913-2009

Di Baldassarre, G., Schumann, G., Bates, P. D., Freer, J. E., \& Beven, K. J. (2010). Flood-plain mapping: A critical discussion of deterministic and probabilistic approaches. Hydrological Sciences Journal, 55(3), 364-376. https://doi.org/10.1080/0262666100368 3389

Dransch, D., Rotzoll, H., \& Poser, K. (2010). The contribution of maps to the challenges of risk communication to the public. International Journal of Dig- ital Earth, 3(3), 292-311. https://doi.org/10.1080/ 17538941003774668

Du, S., He, C., Huang, Q., \& Shi, P. (2018). How did the urban land in floodplains distribute and expand in China from 1992-2015? Environmental Research Letters, 13(3), Article 034018. https://doi.org/10.1088/ 1748-9326/aaac07

Eldho, T. I., Zope, P. E., \& Kulkarni, A. T. (2018). Urban flood management in coastal regions using numerical simulation and geographic information system. In P. Samui, D. Kim, \& C. Ghosh (Eds.), Integrating disaster science and management: Global case studies in mitigation and recovery (pp. 205-219). Elsevier. https:// doi.org/10.1016/B978-0-12-812056-9.00012-9

Folke, C. (2016). Resilience (Republished). Ecology and Society, 21(4), Article 44. https://doi.org/10.5751/ ES-09088-210444

Folke, C., Colding, J., \& Berkes, F. (2003). Synthesis: Building resilience and adaptive capacity in socialecological systems. In F. Berkes, J. Colding, \& C. Folke (Eds.), Navigating social-ecological systems: Building resilience for complexity and change ( $\mathrm{pp}$. 352-387). Cambridge University Press. https://doi. org/10.1017/CBO9780511541957.020

Głosińska, E. (2014). Floodplain management in the context of assessment and changes of flood risk and the environment: A Review. Polish Journal of Environmental Studies, 23(6), 1895-1904. http://www.pjoes. com/pdf-89384-23241?filename=Floodplain $\% 20$ Management\%20in.pdf

Godschalk, D. R. (2003). Urban hazard mitigation: Creating resilient cities. Natural Hazards Review, 4(3), 136-143. https://doi.org/10.1061/(ASCE)15276988(2003)4:3(136)

Hegger, D. L. T., Driessen, P. P. J., Wiering, M., van Rijswick, H. F. M. W., Kundzewicz, Z. W., Matczak, P., Crabbé, A., Raadgever, G. T., Bakker, M. H. N., Priest, S. J., Corinne, L., \& Ek, K. (2016). Toward more flood resilience: Is a diversification of flood risk management strategies the way forward? Ecology and Society, 21(4), Article 52. https://doi.org/10.5751/ ES-08854-210452

Holling, C. S. (1973). Resilience and stability of ecological systems. Annual Review of Ecology and Systematics, 4, 1-23. https://doi.org/10.1146/annurev.es.04. 110173.000245

Holling, C. S. (1986). The resilience of terrestrial ecosystems: Local surprise and global change. In W. C. Clark \& R. E. Munn (Eds.), Sustainable development of the biosphere (pp. 292-317). Cambridge University Press.

Horritt, M. S. (2006). A methodology for the validation of uncertain flood inundation models. Journal of Hydrology, 326(1/4), 153-165. https://doi.org/10.1016/ j.jhydrol.2005.10.027

Hunter, N. M., Bates, P. D., Neelz, S., Pender, G., Villanueva, I., Wright, N. G., Liang, D., Falconer, R. A., Lin, B., Waller, S., Crossley, A. J., \& Mason, D. C. (2008). 
Benchmarking 2D hydraulic models for urban flooding. Water Management, 161(1), 13-30. https://doi. org/10.1680/wama.2008.161.1.13

Hydrologic Engineering Center. (2008). HEC-RAS: River analysis system. User's manual, version 4.0. US Army Corps of Engineers, Hydrologic Engineering Center.

Hydrologic Engineering Center. (2010). HEC-RAS: River analysis system. Hydraulic reference manual, version 4.1. US Army Corps of Engineers, Hydrologic Engineering Center.

Intergovernmental Panel on Climate Change. (2014). Climate change 2014: Synthesis report. Contribution of working groups I, II and III to the fifth assessment report of the Intergovernmental Panel on Climate Change. https://www.ipcc.ch/report/ar5/syr

Intergovernmental Panel on Climate Change. (2018). Global warming of $1.5^{\circ} \mathrm{C}$. An IPCC special report on the impacts of global warming of $1.5^{\circ} \mathrm{C}$ above preindustrial levels and related global greenhouse gas emission pathways, in the context of strengthening the global response to the threat of climate change, sustainable development, and efforts to eradicate poverty. https://www.ipcc.ch/sr15/download

Johannessen, $\AA$. (2015). Integrating flood risk reduction, river basin and resilience management in planning: A case study of Kristianstad, Sweden (Working Paper No. 2015-01). Stockholm Environment Institute. https://mediamanager.sei.org/documents/ Publications/Climate/SEI-WP-2015-Kristianstadfloods-river-basin-management.pdf

Klang, D., \& Klang, K. (2009). Analys av höjdmodeller för översvämningsmodellering [Analysis of elevation models for inundation modeling]. Myndigheten för samhällsskydd och beredskap and Lantmäteriet. https://docplayer.se/docview/57/39936952.pdf

Koivumäki, L., Alho, P., Lotsari, E., Käyhkö, J., Saari, A., \& Hyyppä, H. (2010). Uncertainties in flood risk mapping: A case study on estimating building damages for a river flood in Finland. Journal of Flood Risk Management, 3(2), 166-183. https://doi.org/10.1111/ j.1753-318X.2010.01064.x

Kundzewicz, Z. W., Pińskwar, I., \& Brakenridge, G. R. (2018). Changes in river flood hazard in Europe: A review. Hydrology Research, 49(2), 294-302. https://doi.org/10.2166/nh.2017.016

Levin, S. (1999). Fragile dominion: Complexity and the commons. Perseus Books.

Lewis, J. A., \& Ernstson, H. (2019). Contesting the coast: Ecosystems as infrastructure in the Mississippi River Delta. Progress in Planning, 129, 1-30. https://doi. org/10.1016/j.progress.2017.10.003

Lewis, J. A., Zipperer, W. C., Ernstson, H., Bernik, B., Hazen, R., Elmqvist, T., \& Blum, M. J. (2017). Socioecological disparities in New Orleans following Hurricane Katrina. Ecosphere, 8(9), Article e01922. https://doi. org/10.1002/ecs2.1922

Liao, K.-H. (2012). A theory on urban resilience to floods-A basis for alternative planning practices.
Ecology and Society, 17(4), Article 48. https://doi. org/10.5751/ES-05231-170448

Lim, N. J. (2011). Performance and uncertainty estimation of 1- and 2-dimensional flood models [Master's thesis, University of Gävle]. University of Gävle Repository. http://urn.kb.se/resolve?urn=urn: nbn:se:hig:diva-9642

Lim, N. J. (2018). Modelling, mapping and visualisation of flood inundation uncertainties [Doctoral Dissertation, University of Gävle]. University of Gävle Repository. http://urn.kb.se/resolve?urn=urn: nbn:se:hig:diva-27995

Lim, N. J., \& Brandt, S. A. (2019a). Are feature agreement statistics alone sufficient to validate modelled flood extent quality? A study on three Swedish rivers using different digital elevation model resolutions. Mathematical Problems in Engineering, 2019, Article 9816098. https://doi.org/10.1155/2019/9816098

Lim, N. J., \& Brandt, S. A. (2019b). Flood map boundary sensitivity due to combined effects of DEM resolution and roughness in relation to model performance. Geomatics, Natural Hazards and Risk, 10(1), 1613-1647. https://doi.org/10.1080/19475705. 2019.1604573

Marchese, D., Reynolds, E., Bates, M. E., Morgan, H., Clark, S. S., \& Linkov, I. (2018). Resilience and sustainability: Similarities and differences in environmental management applications. Science of the Total Environment, 613/614, 1275-1283. https://doi.org/ 10.1016/j.scitotenv.2017.09.086

Meerow, S., \& Woodruff, S. C. (2020). Seven principles of strong climate change planning. Journal of the American Planning Association, 86(1), 39-46. https://doi. org/10.1080/01944363.2019.1652108

Meerow, S., Newell, J. P., \& Stults, M. (2016). Defining urban resilience: A review. Landscape and Urban Planning, 147, 38-49. https://doi.org/10.1016/ j.landurbplan.2015.11.011

Merwade, V., Olivera, F., Arabi, M., \& Edleman, S. (2008). Uncertainty in flood inundation mapping: Current issues and future direction. Journal of Hydrologic Engineering, 13(7), 608-620. https://doi.org/ 10.1061/(ASCE)1084-0699(2008)13:7(608)

Montz, B. E. (2000). The generation of flood hazards and disasters by urban development on floodplains. In D. J. Parker (Ed.), Floods (pp. 116-127). Routledge.

Moroni, S., \& Chiffi, D. (in press). Complexity and uncertainty: Implications for urban planning. In J. Portugali (Ed.), Handbook on cities and complexity. Edward Elgar Publishing.

National Research Council. (2012). Disaster resilience: A national imperative. The National Academies Press. https://doi.org/10.17226/13457

Nyström, M., Folke, C., \& Moberg, F. (2000). Coral reef disturbance and resilience in a human-dominated environment. Trends in Ecology and Evolution, 15(10), 413-417. https://doi.org/10.1016/S01695347(00)01948-0 
Pang, A. T., Wittenbrink, C. M., \& Lodha, S. K. (1997). Approaches to uncertainty visualization. The Visual Computer, 13(8), 370-390. https://doi.org/10.1007/ s003710050111

Pappenberger, F., \& Beven, K. J. (2006). Ignorance is bliss: Or seven reasons not to use uncertainty analysis. Water Resources Research, 42(5), Article W05302. https://doi.org/10.1029/2005WR004820

Pappenberger, F., Beven, K. J., Ratto, M., \& Matgen, P. (2008). Multi-method global sensitivity analysis of flood inundation models. Advances in Water Resources, 31(1), 1-14. https://doi.org/10.1016/ j.advwatres.2007.04.009

Pine, J. C. (2015). Hazards analysis: Reducing the impact of disasters (2nd ed.). CRC Press.

Ranzi, R., Bacchi, B., Barontini, S., Ferri, M., \& Mazzoleni, M. (2013). Levee breaches statistics, "geotechnical uncertainty," residual risk in flood hazard mapping. In The wise find pleasure in water: Meandering through water science and engineering. Proceedings of the 35th IAHR World Congress (Vol. 5, pp. 4516-4524). IAHR.

Restemeyer, B., van den Brink, M., \& Woltjer, J. (2018). Resilience unpacked-Framing of 'uncertainty' and 'adaptability' in long-term flood risk management strategies for London and Rotterdam. European Planning Studies, 26(8), 1559-1579. https://doi.org/ 10.1080/09654313.2018.1490393

Ritchie, H., \& Roser, M. (2018). Urbanization [Data set]. Our World in Data. https://ourworldindata.org/ urbanization

Rollason, E., Bracken, L. J., Hardy, R. J., \& Large, A. R. G. (2018). Rethinking flood risk communication. Natural Hazards, 92(3), 1665-1686. https://doi.org/ 10.1007/s11069-018-3273-4
Saksena, S., \& Merwade, V. (2015). Incorporating the effect of DEM resolution and accuracy for improved flood inundation mapping. Journal of Hydrology, 530, 180-194. https://doi.org/10.1016/j.jhydrol.2015.09. 069

Syvitski, J. P. M., Kettner, A. J., Overeem, I., Hutton, E. W. H., Hannon, M. T., Brakenridge, G. R., Day, J., Vörösmarty, C., Saito, Y., Giosan, L., \& Nicholls, R. J. (2009). Sinking deltas due to human activities. Nature Geoscience, 2(10), 681-686. https://doi.org/ 10.1038/ngeo629

Thorne, C. R., Lawson, E. C., Ozawa, C., Hamlin, S. L., \& Smith, L. A. (2018). Overcoming uncertainty and barriers to adoption of blue-green infrastructure for urban flood risk management. Journal of Flood Risk Management, 11(S2), 960-972. https://doi.org/ $10.1111 / \mathrm{jfr} 3.12218$

UN-Habitat. (2016). Urbanization and development: Emerging futures. World cities report 2016. https://unhabitat.org/sites/default/files/downloadmanager-files/WCR-2016-WEB.pdf

van Alphen, J., Martini, F., Loat, R., Slomp, R., \& Passchier, R. (2009). Flood risk mapping in Europe, experiences and best practices. Journal of Flood Risk Management, 2(4), 285-292. https://doi.org/10.1111/ j.1753-318X.2009.01045.x

Wenger, C. E. B. (2017). Flood management in a changing climate [Doctoral dissertation, Australian National University]. Bushfire \& Natural Hazards CRC. https:// www.bnhcrc.com.au/publications/biblio/bnh-5149

Zevenbergen, C., Gersonius, B., \& Radhakrishan, M. (2020). Flood resilience. Philosophical Transactions of the Royal Society A: Mathematical, Physical and Engineering Sciences, 378(2168), Article 20190212. https://doi.org/10.1098/rsta.2019.0212

\section{About the Authors}

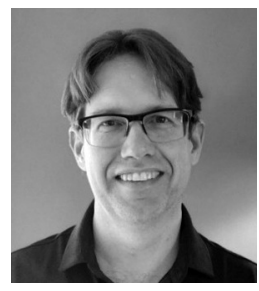

Sven Anders Brandt is Docent (Associate Professor/Reader) in Geospatial Information Science at the University of Gävle, Sweden. He received his MSc and PhD degrees in Physical Geography from Uppsala University, Sweden, and University of Copenhagen, Denmark, respectively. His research ranges from geography didactics, over fluvial geomorphology and river flood risk mapping, to geospatial multicriteria decision analysis.

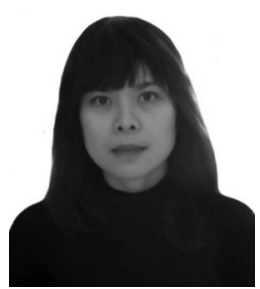

Nancy Joy Lim is a Senior Lecturer at the University of Gävle. She holds a PhD in Geospatial Information Science and has a background in Geography and Geomatics. Her research is primarily focused on modeling, geovisualization, GIS, and spatial analysis. 


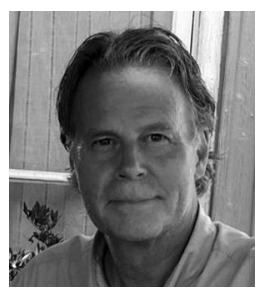

Johan Colding is a highly cited Urban Ecologist and Professor in Sustainability Science at the University of Gävle and the Beijer Institute of Ecological Economics. His expertise covers resilience science, complex adaptive systems, social-ecological urban systems, ecosystem services, and urban planning and design.

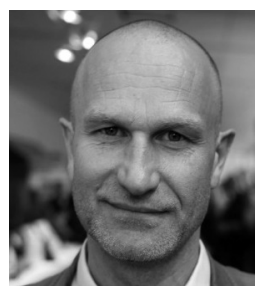

Stephan Barthel is a Professor in Sustainability Science and a highly cited scholar in "Web of Science" $(2019,2020)$. He holds a PhD in Natural Resource Management and a reader degree in Geospatial Information Science. He is the Director of a challenge-driven research direction on urban sustainability at the University of Gävle with the mission to stimulate the integration of climate transformation research with that of social-ecological resilience research. 